\title{
KSZTAŁTOWANIE NAWYKÓW JĘZYKOWYCH W PROCESIE GLOTTODYDAKTYCZNYM (ASPEKT EWOLUCYJNO-ANTROPOCENTRYCZNY)
}

\author{
FORMATION OF LANGUAGE HABITS \\ IN THE GLOTTODIDACTIC PROCESS \\ (EVOLUTIONAL AND ANTHROPOCENTRIC ASPECT)
}

\author{
SYLWESTER JÓZEFIAK
}

\begin{abstract}
This paper characterizes the theory and practice of developing language habits. The author describes some of the ways of forming habits by using glottodidactic methods such as: audio-lingual, cognitive and communicative. The results of the analysis show that the development of language habits should take place in repetitive informal situations, in which people use a foreign language in accordance with their intentions.

Sylwester Józefiak, Uniwersytet Pedagogiczny im. Komisji Edukacji Narodowej w Krakowie, Kraków - Polska.

Inspiracją do napisania niniejszego artykułu stała się potrzeba usystematyzowanego określenia miejsca i roli nawyków językowych w procesie akwizycji języków obcych w dotychczasowej przestrzeni edukacyjnej.

Współczesne wydania encyklopedyczne definiują nawyk jako zautomatyzowany składnik zachowania, formujący się $\mathrm{w}$ procesie wielokrotnego powtarzania i ćwiczenia (Encyklopedia popularna PWN 1992: 552).

Dla pełniejszej ilustracji tego pojęcia warto przyjrzeć się ogólnym warunkom tworzenia nawyków.

Z badań przeprowadzonych przez I.P. Pawłowa nad funkcjami kory mózgowej (w tym nad odruchami warunkowymi), które miały miejsce na przełomie XIX i XX w. i legły u podstaw powstania teorii wyższych czynności nerwowych, a następnie zostały rozwinięte przez innych badaczy, wynikało, że podstawę nawyku stanowi stereotyp dynamiczny, na który składają się: bodziec - reakcja - wzmocnienie (nagroda, pochwała). Współczesne doświadczenia doprowadziły do konkluzji, iż warunkami efektywnego kształtowania nawyków są:
\end{abstract}


- dobry instruktaż słowny uzupełniony pokazem (prezentacją), gdyż przyspiesza on świadome naśladownictwo, eliminuje dużą ilość nieprzydatnych czynności, sprzyja szybszemu promowaniu dobrych wzorów,

- wykonywanie samodzielnych prób, prowadzące do redukcji zbędnych czynności przy podejmowaniu kolejnych prób, wspomagane podawaniem instrukcji wykonania czynności, które wpływają na ich doskonalenie,

- rozkład czynności (ćwiczeń) w czasie sprzyja ugruntowaniu informacji w magazynie pamięci długotrwałej,

- indywidualno-osobnicze właściwości, uzupełnione relacjami człowieka do wykonywanej czynności, tzn. występowanie określonego poziomu motywacji,

- ulepszanie technik ćwiczeniowych, organizacji pracy, wykorzystanie dostępnych pomocy technicznych itp.

Formowanie nawyków językowych, jak dowodzą dotychczasowe badania, jest skuteczniejsze wówczas, gdy ich ćwiczenie odbywa się w różnorodnych sytuacjach językowo-komunikacyjnych oraz na bazie zróżnicowanych materiałów glottodydaktycznych. Szczególnie trudne elementy operacji formowania nawyku wymagają serii dodatkowych ćwiczeń pomocniczych.

Należy podkreślić, że uwzględnianie zjawiska asocjacji (tj. połączenia bodźców wzrokowych, słuchowych i motorycznych) sprzyja bardziej „,elastycznym" nawykowym zachowaniom komunikacyjnym, tzn. swobodniejszemu i spontanicznemu wypowiadaniu się osób uczestniczących w aktach komunikacji językowej.

\section{Kształtowanie nawyków językowych w okresie przednaukowym}

Na etapie przednaukowym, tj. do czasu powstania psychologii eksperymentalnej, zapoczątkowanej przez W. Wundta (1879) oraz wspomnianej wcześniej teorii wyższych czynności nerwowych, nauczanie języków obcych polegało na pamięciowym, werbalnym przyswajaniu gramatyki i leksyki (przy zastosowaniu metody gramatyczno-tłumaczeniowej) lub na wielokrotnym powtarzaniu zdań drogą naśladownictwa (przy nauczaniu metodą bezpośrednią [F. Golin, M. Berlitz] oraz audiolingwalną [L. Bloomfield 1942; Ch. Fries 1945; R. Lado 1961; B.F. Skinner, J.G. Holland 1961]).

Należy zaznaczyć, iż uczenie się pierwszego języka (języka ojczystego) odbywa się na drodze "prób i błędów”, a więc tworzenia przez małe dziecko własnych systemów aproksymacyjnych (interjęzyków), co oznacza stopniowe dostosowywanie hipotez językowych do systemu języka ojczystego. Natomiast przy nauce języka drugiego (obcego) uczący się nie powtarza tej drogi (ontologicznej), gdyż formowanie nawyku następuje wskutek zderzenia się ukształtowanej już znajomości języka ojczystego z kształtującym się dopiero systemem języka obcego. 


\section{Okres naukowy kształtowania nawyków językowych}

Połączenie w latach 40-tych XX wieku osiągnięć językoznawstwa strukturalistycznego, którego przedstawicielami na gruncie amerykańskim byli L. Bloomfield, R. Lado, Ch. Fries, oraz rezultatów badań psychologii behawiorystycznej, zajmującej się warunkowaniem instrumentalnym, której współtwórcą był B.F. Skinner, stworzyło naukowe podstawy do rozwoju nowej teorii nauczania i uczenia się języków obcych.

Szczególne zainteresowanie znajomością języków obcych zaznaczyło się w czasie II wojny światowej. Prowadzono wówczas intensywne kursy nauki języków obcych, głównie dla żołnierzy, kierowanych jako tłumaczy na różne fronty: w Europie, Indochinach, Afryce.

$\mathrm{W}$ okresie tym $\mathrm{w}$ nauczaniu języków obcych rozwinięto metodę audiolingwalną (ustno-słuchową). Jej założenia oparto na podstawach językoznawstwa strukturalistycznego oraz na psychologii behawiorystycznej. Twórcy i zwolennicy metody audiolingwalnej postrzegali język jako zespół nawyków, zaś działanie językowe traktowali jako zjawisko czysto nawykowe (L. Bloomfield 1942).

B.F. Skinner pojmował nawyk w sposób mechaniczny. Jego istotą było połączenie bodźca z określoną reakcją. Proces tworzenia nawyków miał charakter mechaniczny, bezrefleksyjny. Według modelu warunkowania instrumentalnego propagowanego przez Skinnera nawyk mógł powstać poniżej progu świadomości jedynie na drodze wielokrotnych powtórzeń danej reakcji w odpowiedzi na dany bodziec, połączony $\mathrm{z}$ natychmiastowym wzmocnieniem reakcji (nagradzaniem prawidłowej reakcji).

Tak więc, w myśl teorii audiolingwalnej, język był systemem nawyków. Nawyk utożsamiano z operacją motoryczną, dlatego działanie językowe porównywano z takimi czynnościami jak: pływanie, jazda na rowerze, prowadzenie samochodu, biegłe pisanie itp.

Z założeń teorii audiolingwalnej wynikało, że najważniejszą rolę w kształtowaniu nawyków językowych odgrywały ćwiczenia językowe typu "pattern practice", zwane drylami. Zwolennicy tej metody określali nawyki jako zachowania stereotypowe wytworzone $\mathrm{w}$ toku ćwiczeń polegających na wielokrotnym powtarzaniu czynności, aczkolwiek nie wymagających udziału świadomości.

Interpretatorzy teorii audiolingwalnej podkreślali, że działania językowe są zasadniczą, jeśli nie jedyną drogą prowadzącą do ukształtowania nawyków językowych, a przez te ostatnie - kompetencji językowej. Reguły językowe składające się na kompetencję językową, zawarte implicite (domyślnie) w tekstach ćwiczebnych, miały być rekonstruowane przez uczących się $\mathrm{w}$ toku ćwiczeń językowych, albo były aplikowane przez nauczyciela jako czynniki korekcyjno-regulujące, lub też miały pozostawać nie- 
uświadomioną generalizacją sposobów językowego wykonania (performancji) czynności komunikacyjnych. Należy stwierdzić, że owe ćwiczenia ze względu na wielokrotność powtórzeń były dla uczących się języka obcego niezwykle pracochłonne i nużące, nie zapewniając spodziewanego przyrostu wprawy $\mathrm{w}$ posługiwaniu językiem obcym ze względu na to, iż, zdaniem wielu oponentów tej metody, do których należy m. in. J. Henzel (1978), dryl nie gwarantował transferu wyuczonych nawyków na inne sytuacje mowne, mimo iż system owych ćwiczeń rozwinięty został przez Palmera do perfekcji (H.E. Palmer 1943).

Psychologowie-behawioryści głosili, że „nawyk to wytworzony w procesie uczenia się związek bodźca i reakcji, względnie stała dyspozycja do reagowania w określony sposób na określone bodźce" (L. Bloomfield 1942; B.F. Skinner, J.G. Holland 1961).

W celu pełniejszej ilustracji założeń metody audiolingwalnej należy podkreślić, że preferowano $\mathrm{w}$ niej następujące rodzaje ćwiczeń służących kształtowaniu nawyków językowych:

- pattern practice (dryl), stosowane aż do przeuczenia,

- imitacja zdań w ślad za nauczycielem,

- substytucja (wymiana elementów wewnątrz zdania),

- transformacja (przekształcanie),

- wybór spośród 3-4 wariantów,

- zamiana elementów na inne.

Powszechnie znany amerykański lingwista A.N. Chomsky zaproponował zastąpienie strukturalistycznego modelu języka modelem nowym - generatywną gramatyką transformacyjną. Podkreślał on, że język nie ma struktury nawykowej, gdyż, jego zdaniem, działanie językowe polega na kreatywności językowej, przejawiającej się $\mathrm{w}$ tym, że nawet $\mathrm{w}$ tych samych warunkach, w tych samych sytuacjach komunikacyjnych mówiący za każdym razem tworzy nowe zdania, których nigdy przedtem nie wypowiadał. Od tego momentu nastąpił zwrot w nauczaniu języków obcych w kierunku innego niż dotychczas kształtowania nawyków. Przyjęto tezę głoszącą, że język to system reguł.

Pit Corder stał na stanowisku, że "to, czego uczymy, to nie poszczególne reakcje językowe, lecz reguły mówiące, jak reagować" (P. Corder 1973: 129). Wkrótce potem pojawiły się $\mathrm{w}$ glottodydaktyce próby pogodzenia stanowisk L. Bloomfielda i N. Chomsky'ego i wykazania, że ich stwierdzenia są wzajemnie komplementarne, gdyż w języku jest miejsce zarówno na nawyki, jak i działania językowe o charakterze kreatywnym, które wykraczają poza proste czynności nawykowe.

V. Rivers (1972), rozpatrując zagadnienie nawyku syntaktycznego i niemożność jego przeniesienia do nowej struktury zdaniowej bez wcześniejszego uświadomienia reguły użycia owej struktury, potwierdziła tym samym 
potrzebę uwzględniania świadomości w procesie kształtowania nawyków. Jej zdaniem, jedne elementy języka, jak: wymowa, końcówki fleksyjne, cechy formalne struktur syntaktycznych (jako układy zamknięte), są realizowane w sposób całkowicie nawykowy przez osobę posługującą się danym językiem obcym. Natomiast pozostałe elementy języka wynikające z planu ekspresji, jak: wybór określonych konstrukcji wypowiedzi, odpowiednich jednostek leksykalnych, stanowią przejaw kreatywności językowej, nie dając się sprowadzić do działalności nawykowej. Elementy te funkcjonują w obrębie układów otwartych języka; są one funkcją indywidualnego wyboru użytkownika języka. Chodzi o to, aby uczeń nauczył się automatycznie reagować na wystąpienie określonej formy gramatycznej użyciem innej określonej formy gramatycznej.

W latach 70-80-tych XX wieku W. Marton, posługując się terminem nawyk generatywny, zapożyczonym od angielskiego psycholingwisty R. Leesona (1975: 7), który oznacza zinternalizowaną lub całkowicie zautomatyzowaną regułę gramatyczną, oraz oparłszy się na tezie amerykańskiego psycholingwisty J. Carrolla głoszącej, że w nauczaniu języka obcego można stopniowo przechodzić od świadomego stosowania reguł do działania nawykowego, stworzył glottodydaktyczną koncepcję nauczania poszczególnych podsystemów języka obcego, polegającą na kierowanym odkrywaniu reguł, świadomie uchwyconych zasad (zwłaszcza w odniesieniu do składni). Podobne stanowisko prezentował amerykański glottodydaktyk K. Chastain (1976).

Należy dodać, że już w latach 60-tych dwudziestego stulecia niektórzy glottodydaktycy i psychologowie rosyjscy, stojąc na stanowisku bynajmniej nie negującym przydatności nawyku językowego, twierdzili, iż w warunkach zinstytucjonalizowanej nauki języka obcego oparcie procesu tworzenia nawyków i sprawności językowych powinno polegać na świadomej analizie zjawisk językowych, gdyż działanie według reguły maksymalnie skraca czas nauczania i prowadzi do większej efektywności (W. Artiomow 1967: 31; A.A. Leontjew 1970).

Kognitywna koncepcja kształtowania nawyków językowych zareprezentowana przez W. Martona wyraża się modelem glottodydaktycznym złożonym z trzech ogniw: świadome uchwycenie - praktyka językowa = zinternalizowana reguła, tj. ćwiczenia gramatyczne, czynności komunikacyjne. Jak wynika z tej koncepcji, kognitywna interpretacja strategii kształtowania nawyków językowych zwróciła się $\mathrm{w}$ przeciwnym kierunku niż audiolingwalizm.

Początkowe ogniwo modelu zakłada świadome uchwycenie zjawiska gramatycznego na drodze obserwacji i kierowanego odkrycia (z wykorzystaniem indukcji i dedukcji), co równa się przyswojeniu wiedzy metajęzykowej o tym, jakich środków przyswajanego języka użyć w danej sytuacji, oraz norm sytuacyjnych użycia tych środków w konstruowanych zdaniach. 
Drugie ogniwo obejmuje zadania językowe ćwiczebne, mające doprowadzić do osiągnięcia ich technicznej poprawności. W ogniwie trzecim uformowane nawyki generatywne winny znaleźć zastosowanie w czynnościach stricte komunikacyjnych i stanowić wewnętrzną regulację rozumową tych działań językowych.

W. Marton twierdzi, że w działaniu językowym w zakresie składni zachowujemy się tak, jakbyśmy posługiwali się regułami (byli kierowani systemem reguł zinternalizowanych w umysłach), a nie nawykami. Dlatego autor proponuje nauczanie systemu fonicznego, intonacyjnego, akcentuacyjnego, gramatycznego i składniowego przy świadomym użyciu systemu reguł w czynnościach komunikowania się. W praktyce oznacza to podawanie wskazówek, reguł, a nawet sterowanie ich zastosowaniem. Tak więc proces glottodydaktyczny powinien obejmować zarówno elementy uczenia się ze zrozumieniem, jak i niezbędną ilość działań mechanizujących, służących kształtowaniu wymowy, akcentuacji, fleksji, intonacji. W. Marton odrzuca "dryl” jako technikę ćwiczebną w procesie kształtowania nawyków.

W metodzie kognitywnej stosowano następujące rodzaje ćwiczeń: transformacyjne, translatorskie i retranslatorskie oraz konstrukcyjne.

W latach 80-tych w kilku ośrodkach naukowych Rosji i w Polsce ukształtowała się nowa metoda nauczania języka obcego, nazwana teorią komunikacyjno-czynnościową. Naukowe podstawy rozwoju tej koncepcji stworzyli: B. Bielajew, A.A. Leontjew, J.I. Passow, O.D. Mitrofanowa, W.G. Kostomarow, N.F. Tałyzina, a w Polsce jej zwolennikiem stał się W. Woźniewicz. Teoria działalności językowej głosi, że

\footnotetext{
jeśli jakiś produkt lub właściwość są rezultatem konkretnej działalności, to również proces interioryzacji nawyków językowych dokonuje się w toku realizacji działań i czynności mownych w ramach określonej działalności pozajęzykowej. Nie tyle częstotliwość i ilość powtórzeń, operacji i działań z materiałem językowym, ile przede wszystkim częstotliwość użycia materiału w czynnościach mownych, w językowym komunikowaniu się realizowanym $\mathrm{w}$ atrakcyjnych dla ucznia rodzajach działalności pozajęzykowej, prowadzi do interioryzacji reguł językowych, do ukształtowania się nawyków językowych, do umiejętności realizacji czynności mownych, do kompetencji językowo-komunikacyjnej - jako produktu docelowego (W. Woźniewicz 1987b: 126).
}

Na obecnym etapie rozwoju glottodydaktyki (por. W. Woźniewicz 1987a, 1987b; N.F. Tałyzina 1980) w nauczaniu języków obcych preferuje się model tzw. słabego sterowania "nauczeniowego", uwzględniający pełną podmiotowość uczącego się (orientacja antropocentryczna), polegający na formowaniu języka bazowego, tj. nawyków artykulacyjno-intonematycznych i akcentuacyjnych oraz leksykalno-gramatycznych z elementami kulturowymi przy udziale świadomości ucznia pod pełną kontrolą nauczyciela, 
a następnie stopniowe rozwijanie umiejętności mówienia poprzez działanie językowe realizowane przez ucznia (przy zredukowanym do minimum udziale nauczyciela w ostatniej fazie działalności mownej), kiedy to uczeń staje się samosterowalny. Według teorii komunikacyjno-czynnościowej nawyki językowe są kształtowane przy udziale świadomości w realnych czynnościach komunikowania się.

Rosyjski glottodydaktyk J.I. Passow zaproponował definicję nawyku językowego, głoszącą, że jest to zdolność wykonywania względnie samodzielnych czynności w systemie działalności świadomej, która dzięki istnieniu całego kompleksu cech stała się jednym z warunków wykonania tych czynności (J.I. Passow 1989).

W glottodydaktyce, za J.I. Passowem, przyjęto następujący podział nawyków:

a) nawyki mowne (leksykalne, gramatyczne, intonacyjne),

b) nawyki ruchowe (np. szybkie pisanie, ukryte powtarzanie przy cichym czytaniu),

c) nawyki ruchowo-mowne (wymowa dźwięków, technika pisania lub głośnego czytania popartego gestykulacją).

Nawyki z grupy pierwszej łączą się ściśle z nawykami grupy trzeciej ze względu na obecność pierwiastka sytuacyjności i kontekstu językowego (J.I. Passow 1989).

Do podstawowych cech nawyków należy automatyzacja, na którą składają się:

- szybkość przebiegu czynności,

- całościowość i płynność czynności,

- ekonomiczność (brak zbędnych działań),

- niski poziom napięcia (np. przy pisaniu liter przez dzieci i dorosłych),

- łatwość wzbudzania wyćwiczonego stereotypu działania językowego,

- elastyczność, tj. zdolność włączania się do nowej sytuacji komunikacyjnej.

W metodzie komunikacyjno-czynnościowej obok ćwiczeń wymienionych w poprzedniej grupie (kognitywnych) stosuje się ćwiczenia konstrukcyjne oparte na tekstach, na dodatkowych mediach oraz zadaniach komunikacyjnych opartych na mediach i nie opartych na nich, związane z symulowanymi lub autentycznymi sytuacjami językowymi.

Reasumując rozważania na temat nawyków językowych, należy stwierdzić, że od lat 40-tych XX wieku do chwili obecnej poglądy badaczy przeszły swoistą ewolucję, traktując język najpierw jako system nawyków, następnie (lata 60-70) jako system reguł, obecnie zaś nawyki językowe 
traktuje się jako kategorię kształtowaną przy udziale świadomości w realnych czynnościach komunikowania się.

Powyższe teoretyczne rozważania znajdują praktyczne odzwierciedlenie w opracowywanych współcześnie modelach glottodydaktycznych.

Tak więc zaproponowany przez J. Henzla bilingwalny model kreowania wypowiedzi w języku obcym przez studentów filologii rosyjskiej stanowi proces obejmujący pięć faz-poziomów, które można zaprezentować $\mathrm{w}$ postaci następującego schematu:

Poziom I. Intencja mowna.

Poziom II. Mowa wewnętrzna A (ciągi pojęciowo-obrazowe z włączeniem leksemów języka ojczystego).

Poziom III. Mowa wewnętrzna B (werbalizacja, gramatykalizacja i fonacja wewnętrzna w języku ojczystym): 1) wybór struktury syntaktycznej; 2) wybór leksemów; 3) wybór środków morfologicznych; 4) wypełnienie struktury leksemami gramatykalizowanymi; 5) fonacja wewnętrzna.

Poziom IV. Mowa wewnętrzna B1 (werbalizacja, gramatykalizacja i fonacja wewnętrzna w języku obcym): 1) wybór struktury syntaktycznej; 2) wybór leksemów; 3) wybór środków morfologicznych; 4) wypełnienie struktury leksemami gramatykalizowanymi; 5) fonacja wewnętrzna.

Poziom V. Mowa zewnętrzna (zewnętrzna fonacja).

Autor projektu uważa, że optymalizacja procesu kreowania mowy obcojęzycznej polega na zintensyfikowaniu procesu przekodowywania, a w jego efekcie - na zwiększeniu efektywności operacji refleksji momentalnej, polegającej na błyskawicznym wyodrębnieniu z pamięci i operatywnym wykorzystaniu kwantów informacji lingwistycznej lub tekstowej (J. Henzel 1992: 2).

Zdaniem piszącego niniejszy artykuł, kształtowanie nawyków lingwistycznych i nabywanie pełnej kompetencji lingwistycznej $\mathrm{w}$ gimnazjach i szkołach średnich winno odbywać się

w oparciu o elementy podstawy orientującej, tj. komentarz lingwistyczny + paradygmaty, algorytmy gramatyczne, tablice syntetyzujące materiał lingwistyczny, i bazować na zasadach mocnego sterowania "nauczeniowego", tzn. przebiegać fazowo: prezentacja - utrwalanie $\mathrm{w}$ toku czynności ćwiczebnych quasi-komunikacyjnych - wdrażanie w zbliżonych do naturalnych czynnościach komunikowania się (S. Józefiak 1999: 66-92).

Jeżeli uwzględnimy postulat N.F. Tałyziny (1980), w myśl którego zadaniem nauczyciela języka obcego jest „stopniowe zwijanie informacji językowej", to w przypadku nauczania języka obcego w szkołach różnych poziomów edukacyjnych takie podejście może polegać na wstępnej cało- 
ściowej prezentacji paradygmatu/reguły językowej oraz serii przykładów praktycznych podawanych najpierw w izolacji, a następnie $\mathrm{w}$ kontekście zdań pojedynczych zawartych $\mathrm{w}$ tekście, dalej $\mathrm{w}$ zdaniach przeznaczonych do tłumaczenia. Natomiast na wyższych etapach zaawansowania językowego uczniów należy odwoływać się jedynie do skondensowanej postaci reguły, tzn., jak to określa J. Henzel (1996), kwantu informacji językowej lub tekstowej, tj. przywołania kilku najważniejszych informacji o danym zjawisku, wskazujących na wyróżniki jego funkcjonowania w danym języku. Uczeń powinien stopniowo zakodowywać je w pamięci.

Suma przechowywanej w pamięci długotrwałej przyswajanej i stopniowo redukowanej do postaci "kwantów" informacji lingwistycznej będzie po zakończeniu danego etapu/kursu nauczania języka obcego z jednej strony świadectwem aktualnego poziomu kompetencji językowej ucznia, z drugiej - rezultatem algorytmizująco-kwantujących działań nauczyciela ukierunkowywanych permanentnie na osobę uczącego się.

Na podstawie powyższych spostrzeżeń opartych na obserwacji uczestniczącej prowadzonej zarówno wśród uczniów szkół podstawowych, jak i studentów starszych lat filologii rosyjskiej piszący te słowa doszedł do konkluzji, iż uczeń z ogólnego tła systemu językowego zakodowanego na etapach reprodukcji i transformacji pracy $\mathrm{z}$ tekstami powinien umieć błyskawicznie w przypadku zaistnienia takiej konieczności wyodrębnić niezbędną porcję informacji językowej, by móc posłużyć się nią w celu eliminacji, a nawet przewidywania błędu(-ów) (imprintingu) (por. J. Henzel 2004) zarówno w mowie ustnej, jak również pisemnej typu kreatywnego (tzn. wypracowywania mechanizmu refleksji momentalnej). Etapowi teoretycznemu zapoznawania się z kodem obcojęzycznym winny towarzyszyć ćwiczenia ustne i pisemne.

"Zwijanie" informacji lingwistycznej do postaci kwantów można zilustrować w sposób następujący (proces lingwistyczny):

1. Prezentacja paradygmatu w postaci całościowej, np. czasownik (etap wstępny):

2. Kwant informacji (etap finalny):

Znak miękki w języku rosyjskim piszemy:

a) w bezokoliczniku czasownika,

b) w 2 osobie czasu teraźniejszego i przyszłego prostego,

c) w niektórych formach trybu rozkazującego,

d) w czasownikach zwrotnych (plus po jednym ilustrującym je przykładzie).

Znak twardy w jezyku rosyjskim piszemy:

a) po przedrostkach rdzennie rosyjskich i nierosyjskich zakończonych na twardą spółgłoskę przed wyrazami rozpoczynającymi się od liter: e, я, ё, ю, 
b) w przymiotnikach złożonych z liczebników 2, 3, 4 przed wyrazami rozpoczynającymi się od liter: e, я, ё, ю itd. zwrotnych (plus po jednym ilustrującym je przykładzie).

Równolegle do „zwijanej” informacji lingwistycznej należy „rozwijać” kompetencję komunikacyjną uczniów, co można wyrazić przy pomocy modelu (proces komunikacyjny):

1. Konstruowanie prostych zdań.

2. Konstruowanie krótkich (kilkuzdaniowych) komunikatów pisemnych oraz ustnych.

3. Konstruowanie dłuższych komunikatów językowych (monologowych i dialogowych).

Procesy - lingwistyczny i komunikacyjny - powinny przebiegać równocześnie (S. Józefiak 2002: 413-418).

Naszym zdaniem, im słabiej rozwinięty system dekodowania przez ucznia informacji lingwistycznej (kwantowej), tym niższy obserwuje się u niego poziom ukształtowania kompetencji komunikacyjnej i wynikającej z niej możliwości swobodnego porozumiewania się językiem obcym w różnorodnych sytuacjach życiowych.

Reasumując, należy podkreślić, że na początkowym etapie mówienia lub pisania $\mathrm{w}$ języku rosyjskim lub innym języku obcym system redukcyjno-kwantowy powinien pełnić rolę „instrumentarium" służącego unikaniu eliminacji błędów językowych (artykulacyjnych, intonacyjnych, akcentuacyjnych, gramatycznych, leksykalnych $\mathrm{i}$ in.), natomiast na etapie zaawansowania komunikacyjnego winien stanowić pomocną "podpórkę" tylko $\mathrm{w}$ niezbędnych przypadkach, bowiem, w trakcie akwizycji języka obcego jego udział należy stopniowo minimalizować. Poznane kwanty informacji lingwistycznej winny pozostawać w przestrzeni pamięci długotrwałej ucznia $\mathrm{w}$ gotowości do użycia w sytuacjach spowodowanych jego wahaniami językowymi (pauzami hezytacji) (por. J. Henzel 1992: 2), nagminnie występującymi $\mathrm{w}$ początkowych i średniozaawansowanych etapach działalności komunikacyjnej.

Należy dodać, że nawyki językowe uformowane na drodze kognitywnych zachowań $\mathrm{w}$ trakcie realnych aktów komunikacji (tzn. w procesach czynnego użycia języka w sytuacjach zgodnych z intencjami mówiących) powinny stopniowo stawać się trwałymi składnikami przyswajanego kodu języka obcego. Prekursorem i propagatorem powyższej, jakże ważnej zasady nauczania języków obcych w myśl obecnie stosowanej na różnych szczeblach edukacyjnych w Polsce metody komunikacyjnej, jak wcześniej wspomniano, pozostaje W. Woźniewicz (1987a; 1987b).

Zawarte w niniejszym artykule rozważania stanowią jedynie częściowe odzwierciedlenie dokonujących się $\mathrm{w}$ glottodydaktyce zmian zorientowa- 
nych na osobę ucznia/studenta, określanych mianem podejścia antropocentrycznego, którego szczegółowymi parametrami i charakterystyką zajmuje się piszący te słowa $\mathrm{w}$ przygotowywanej rozprawie profesorskiej.

\section{Bibliografia}

А р т е м о в В.А., 1966. Психология обучения иностранным языкам, Москва: Изд-во Моск. ун-та.

А р т е м о в В.А., 1967. Основные проблемы современной психологии обучения иностранным языкам, „Иностранные языки в школе”, № 1.

Б е л я е в В., 1965. Очерки по психологии обучения иностранным языкам, Москва.

B 1 o o m f i e 1 d L., 1942. Outline Guide for the Practical Study of Foreign Languages. Linguistic Society of America.

C h a s t a i n K., 1976. Developing Second-language Skills: Theory to Practice, Chicago: Rand Nc Nally College Publishing Co.

C h o m s k y A.N., 1957. Syntactic Structures. Haga-Paryż.

C h o m sk y A.N., 1966. Linguistic theory. Contexts. New York.

C o r d e r P., 1976. Introducing Applied Linguistics. Harmonds Worth. Middlessex Penguin Books Inc.

Encyklopedia popularna PWN. 1992, Warszawa: PWN, s. 5, 552.

F r i e s C.C., 1945. Teaching and Learning English as a Foreign language, Ann Arbor: The University of Michigan Press.

Н е $\mathrm{n}$ z e 1 J., 1992. Билингвальная модель порождения высказывания и вопросы оптимизации преподавания русского языка как иностранного, „Русский язык за рубежом”, № 2, s. 89-96.

Н е n z e 1 J., 1996. Квантование мингвистической информации и его применение в лингводидактических материалах по русскому языку, [w:] Вопросы лингвистики и лингводидактики. Материалы конференции МАПРЯЛ, Краков 23-24.IV.1996, под ред. T. Жеберек, Kraków: Wydawnictwo Naukowe WSP, s. 214-222.

J ó z e f i a k S., 1999. Sterowanie procesem opanowywania mowy produktywnej na etapie przyswajania podstaw jezzyka obcego (na materiale języka rosyjskiego), Kraków: Wydawnictwo Naukowe AP, s. 66-92.

J ó z e f i a k S., 2002. Проект отбора лингводидактических материалов по практикуму русского языка для студентов 3-го курса филологии Краковской педагогической академии, [w:] Новое в теории и практике описания и преподавания русского языка. Материалы IX Международной научно-методической конференции, проходивщей 1617 мая 2002 г., Варшава. Международная Ассоциация Преподавателей Русского Языка и Литературы (МАПРЯЛ). Российский Центр Науки и культуры в Варшаве, Ассоииациия Сотрудничества Польша-Восток, Общество Польша-Россия, Польское Общество Русистов, редколлегия И.Л. Тетерев, Т. Медзиньски, Варшава, s. 413-418.

П а с с о в Е.И., 1989. Основы коммуникативной методики обучения иноязыному обучению, Москва: Изд-во „Русский язык”, s. 33-38.

К о с т о м а р о в В.Г., М и т р о ф а н о в а О.Д. и др., 1990. Методика преподавания русского языка как иностранного. Москва: Изд-во „Русский язык”. 
L a d o R., 1961. Language Testing, London: Longman.

L e e s o n R., 1975. Fluency and language Teaching, London: Longman.

Л е о н т ь е в А.А., 1969. Язык и речъ, Москва: Изд-во „Просвещение”.

Л е о н т ь е в А.А., 1970. Некоторые проблемы обучения русского языку как иностранному, Москва: Изд-во Моск. ун-та.

M a r t o n W., 1970. Optymalizacja nauczania języków obcych w szkole, Warszawa: WSiP.

P a $1 \mathrm{~m}$ e $\mathrm{r}$ H.E., 1943. The Oral Method of Teaching Languages. Cambridge. 4 (tłum. ros.). 1966. Устный метод, Москва.

R i v e r s V., 1968. Teaching Foreign language Skills, Chicago: The University of Chicago Press.

R i v e r s V., 1972. Speaking in Many Tongues. Essays in foreign-language teaching 8-13. Cambridge University Press.

S k i n n e r B.F., H o 11 a n d J.G., 1961. The Analysis of Behaviour, Nowy York.

$\mathrm{T}$ a $\nmid$ y z i n a N.F., 1980. Kierowanie procesem przyswajania wiedzy, Warszawa: WSiP.

W o źn n e w i c z W., 1987a. Kierowanie procesem glottodydaktycznym, Warszawa: PWN.

W o ź n i e w i c z W., 1987b. Metodyka lekcji języka rosyjskiego, Warszawa: WSiP. 